\title{
A Igreja das Minas e a lgreja dos Gerais: uma análise comparada da recepção do Concílio Vaticano II nas Igrejas locais de Mariana e de Montes Claros
}

Orientador: Luís Corrêa Lima

Doutorando: Fábio Vieira de Souza

Área de Concentração: Teologia Sistemático-Pastoral

Linha de Pesquisa: Religião e Modernidade

Projeto de Pesquisa: História da Igreja e Modernidade: Permanências e Mudanças

O presente trabalho retoma de forma sistemática, o percurso que marcou a caminhada do Povo de Deus nas Arquidioceses de Mariana e de Montes Claros, com ênfase no período pós-conciliar. A partir deste objetivo, revisitamos a história da formação do catolicismo nestas duas Igrejas locais do Estado de Minas Gerais, o que nos permite perceber como a Igreja Católica se consolidou na região mineradora e no norte de Minas. De posse destes dados históricos lidos á luz da teologia da recepção, voltamos o nosso olhar sobre Segundo Sínodo de Mariana e para a Terceira Assembleia diocesana de Pastoral de Montes Claros. A partir destes eventos diocesanos podemos verificar como o Vaticano II foi recebido por estas dioceses cerca de vinte e cinco anos depois da promulgação dos textos do Concílio.

Palavras-chave: Concílio Vaticano II. Teologia da Recepção. 